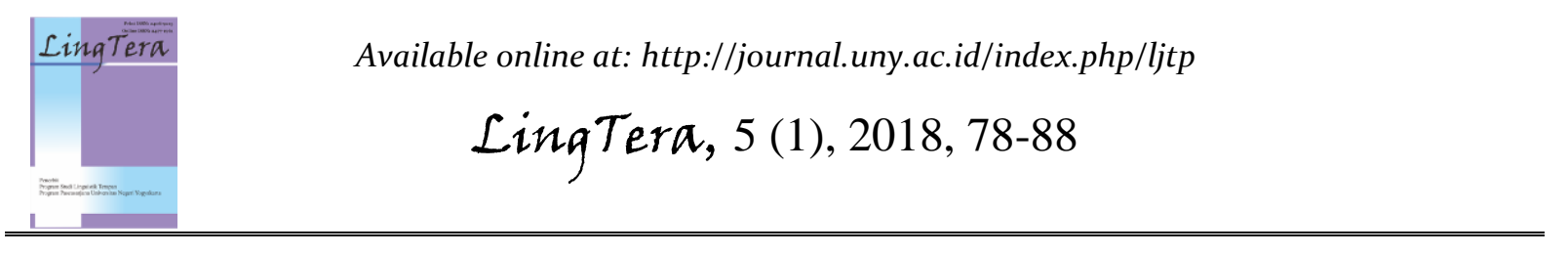

\title{
Developing content and language integrated English speaking materials for accounting students
}

\author{
Dominique Savio Nsengiyumva \\ University of Burundi. Rohero, Boulevard du 28 Novembre, Bujumbura, Burundi \\ Corresponding Author. Email: dominiquesavio2014@gmail.com \\ Received: 27 April 2017; Revision: 1 October 2018; Accepted: 8 October 2018
}

\begin{abstract}
This study aimed at developing content and language integrated English speaking learning materials for the students of international accounting study program to help them learn, practise and improve their speaking skills first in content subjects classes and then in their future career. The study involved 27 third year students of Accounting Department, Faculty of Economics, Yogyakarta State University. The data were collected through an interview, classroom observation, and a students' questionnaire. The research findings show that, the students prefer: business, accounting basics, accounting concepts, and financial accounting accounting contents topics. In terms of classroom activities, students preferred making presentations, discussion, dialogues, role-plays, and making descriptions. The students have difficulties in discussions/debates, pronunciation, grammatical structures, and knowledge of specific vocabulary items. Their priorities for speaking English include presentations, discussions, questions and answers, descriptions, and using specific vocabulary items. Their preferences on the components of the English speaking learning materials include conversations/ dialogues, grammatical features, specific vocabulary items, presentations, and discussions/debates. The evaluation of the developed materials falls in the Very Good category for both experts and students' evaluation.
\end{abstract}

Keywords: content and language integrated materials, English, accounting students, speaking skills.

How to Cite: Nsengiyumva, D. (2018). Developing content and language integrated English speaking materials for accounting students. LingTera, 5(1), 78-88. doi:http://dx.doi.org/10.21831/lt.v5i1.13829

http://dx.doi.org/10.21831/lt.v5i1.13829

\section{INTRODUCTION}

In the 21st century, many universities make use of English in order to become worldclass universities. According to Ruiz-Garrido, Palmer, \& Fortanet-Gómez (2010, p.1), English has become a current international lingua franca of communication because of the spread of science and technology. Both globalization of economy and the universities that are becoming international have made English a world language of communication. Because this language is becoming crucial in many countries over the world, it has become a medium of instructions in many universities. This can be realised from the actual requirement of English test scores in order to be accepted in many universities in the world. In Indonesia, the importance of English can be seen from the requirment from Indonesian universities to have an acceptable TOEFL score for university students to graduate.

Yet, many students are still struggling to use English, especially when it comes to speaking. One of the strategies to be a world-class university is to use world language in specific programs. The main language used in many universities as an international language is English. This was also discussed by Richards $(2015$, p.7) by saying that the current trend of internationalization of higher education is operated through English. It can therefore be said that this is the case of international programs in Yogakarta State University where English is given much importance. Students of international programs in YSU are not only required to have a good score in TOEFL, they also have to take most of the subjects in English as one of the standards in international programs. In Yogyakarta State University, at least $75 \%$ of the classroom activities are expected to be conducted in English, in 


\section{LingTera, 5 (1), 2018 - 79}

Dominique Savio Nsengiyumva

international program (or programs of excellence).

The students of international programs in Accounting at YSU have the same problem realised by Ogle \& Correa-Kovtun (2010) in Sasson (2013, p.24) as they put that students are "stuck in the middle ground of being conversational in English, but lacking in the breadth of English needed for content area success". To help these students to be more comfartable in their classroom content subjects activities, students need to learn English that embodies materials specific to their field of study. Content and language integrated materials can assist students to overcome the challenges of language in this situation.

According to Dalton-Puffer (2007, p.1) Content and Language Integrated Learning (CLIL) is an educational area whereby a language different from the students' first language is used as educational medium of instruction. He argues that "CLIL resembles other forms of bilingual education programmes such as content-based instruction and immersion education" that exist in North American learning contexts while de Zarobe, \& Catalán (2009, p. 41) view CLIL as the "post method pedagogy" in second language learning.

The educational setting for international program in YSU is an image of what DaltonPuffer (2007, p. 1) described students have to study content subjects in English whereas English is used as a foreign language in Indonesia. For the academic use of English, DudleyEvans \& St John (1998, p.112) distinguish four types of EAP situations. EAP in English speaking countries, EAP in a ESL situations, EAP situations in which only certain subjects are taught in English, EAP situations where subjects courses are taught in the national language. The case under study enters the third situation. That is "EAP situations where certain subjects are taught in English." In this situation the international students in YSU are expected to use more English in their lectures but they still have other classes in Indonesian. On the other hand, Devos (2016, p.11) puts that CLIL is "an educational approach in which students acquire a FL while learning meaningful content matter". The importance of CLIL in this study is that of handling specific content while teaching and learning to effectively communicate in English.

CLIL is not standing alone but it is in the setting of other language teaching theories and approaches. As there are still controversial dis- cussions on the scope of CLIL, this study looked at CLIL as a setting not a method for English language teaching. This was inspired by Coyle (2010, p.vii) through Cenoz, Genesee, and Gorter (2013, p.11) who asserts that in CLIL "there are no set of formula and methods for CLIL ...". Therefore the steps that were followed to develop the students materials were those proposed by Communicative Language Teaching Approach (CLT) advocated by Littlewood \& Williams (1981, p. 86).

Littlewood \& Williams (1981, p. 86) discussed with examples the steps of CLT activities which include pre-communicative activities (Structural activities, Quasi-communicative activities), Functional communicative activities, Communicative activities, and Social interaction activities.

Littlewood \& Williams (1981, p. 86) puts that there is no clear line-cut between these categories and subcategories. The difference resides in the emphasis and oriantation of individual learners.

In the sense to find out usefulness of the the settings of CLIL, Révész, Ekiert, \& Torgersen (2014, pp. 7-8) conducted a research where they were expected to assess the effect of complexity, accuracy, and fluency on communicative adequacy in oral task performance. Révész, Ekiert, $\&$ Torgersen study shows us that in speaking, it is not only fluency that is expected from learners. There is also a need for grammatical features, appropriate vocabulary items and pronunciation awareness.Thus, both fluency and accuracy need to be taught and in English speaking classes for foreign users. Parsons (2017, p. 11) implemented Language Related Episodes and formative peer assessement in classroom oral discussions where "the use of L1 and L2 was tightly controlled, and a focus on accuracy was encouraged." He found that students were aware of their language and they helped one onother in their construction of dialogues. On the other hand, Devos (2016, pp. 45-46) analyzed many researches in CLIL classrooms and highlighted different findings in terms of language activities in CLIL classrooms especially in speaking classroom opportunities. These findings include the use of role-play to improve the participant fluency. He then found that students tend to produce elaborated output more in a students-centered class than in teacherled class.

Finally, the development of materials for students of international program in Accounting at YSU should help to solve the problem realized 


\section{LingTera, 5 (1), 2018 - 80}

Dominique Savio Nsengiyumva

by (Ogle \& Correa-Kovtun, 2010) in Sasson (2013, p.24) as they discuss obstacles students encounter in learning to speak English in contentareas. They put that students are "stuck in the middle ground of being conversational in English, but lacking in the breadth of English needed for content area success". They realise that it is possible for students to appear proficient in interpersonal communication, but students of content-areas do not simply need the interpersonal communication, they need to move beyond this and practise communication skills that help them to study academic and disciplinary language in order to be successful in academic content related subjects.

\section{METHOD}

This developmental study refers to the model of instructional materials writing suggested by Jolly and Bolitho through Tomlinson (2011, p. 20). The model was adapted and grouped into seven developmental steps consisting of: (a) identification of needs, (b) designing a course syllabus, (c) developing the materials, (d) evaluating the first draft, (e) conducting try-out and revising the first draft, and (f) writing the final draft. There was a limited tryout that involved seven students of the Department of Accounting, Faculty of Economics, Yogyakarta State University. After the limited tryout, there was a real tryout which involved 27 semester VI students of Accounting Department, Faculty of Economics, Yogyakarta State University. The instruments for data collection were interview guide, observation guide, and a students' questionnaire for needs analysis. The data for the evaluation of the appropriateness of the developed materials were collected using experts' and students' evaluation sheets. Analysis of data was done using the descriptive statistics and content analysis methods.

\section{RESULT AND DISCUSSION}

\section{Result}

To develop the materials appropriate to students of accounting in the international study program (class of excellence), an assessement of needs was compulsory. These needs included Necessities, wants, and lacks. Thus, items of the instruments for data collection intended to get data in order to know students necessities, lacks and wants according to the learning of English speaking based on CLIL and using CLT steps of classroom activities development.
Contexts of English Use After University Study

Data were collected in order to know students' contexts where they think they will need to use English after university study. This may be referred to as English for their future workplace communication. Newton and Kusmierczyk (2011, pp. 66-67) challenges the language materials that are more interested in "holistic communicative environment and on the communicative ideology of the workplace" without focusing on "needs analysis and course evaluations". They contend that there is a growing interest in workplace such as physics labs, hospitals, legal practices, hairstyling salons, call centers, manufacturing plants, professional workplaces, and government and civil service".

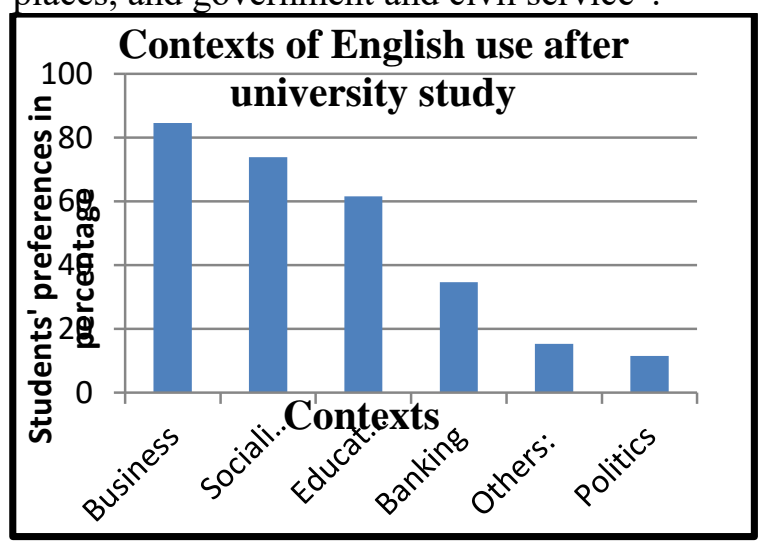

Figure 1. Contexts of English use after university study

The chart shows that most students think that they will have to speak English in business context with a percentage of $85 \%$. Besides, a percentage $(74 \%)$ think that they will need to socialize in English. Students also believe that they will need English in education (62\%). There are students who think they will need to talk about banking after their university study. While context related to politics is not significally mentioned (only 12\%). It can be deduced that the context of English use in students' future career is mainly "business".

Data were also collected through interview. The results show that students are convinced that they will need to travel abroad in the ASEAN community and communicate with others. They will also need to find jobs or create their own businesses. Besides, they commented that they should be ready to use English and work anywhere in the global era.

Knowing the context in which students think they will need to use English is not complete. There was a necessity to know what 
activities they think they will do in the job context. This helped to develop materials based on these activities in order to familise students with the activities.

\section{Students' Job Activities After University Study}

Data were collected for the purpose to inquire about students' job activities that they think they will most likely be involved in and that will necessitate the use of English after their university study.

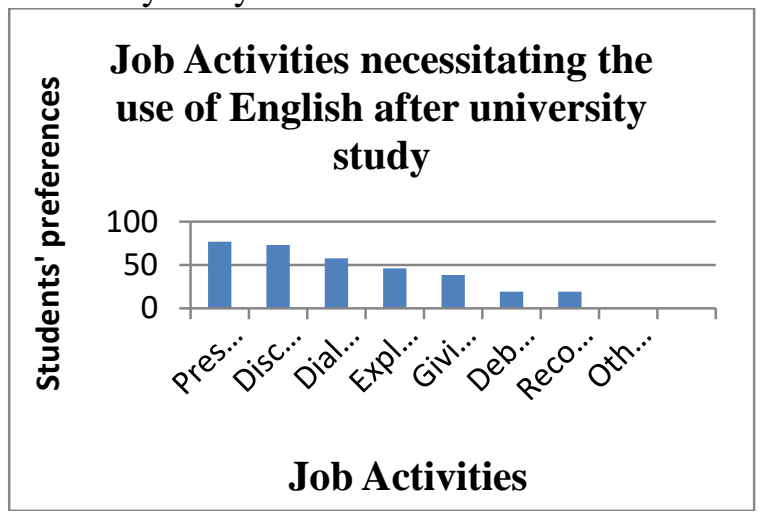

Figure 2. Students' job activities necessitating the use of English after university study

The results from data from students' questionnaire indicate that students think that they will be involved more in three main job activities. These are: presentations (77\%), discussions (with 73\%), and dialogues/ conversation (with 58\%). Topics like giving instructions and giving explanations, recounts and debates receive a percentage which is not significant enough.

\section{$L A C K S$}

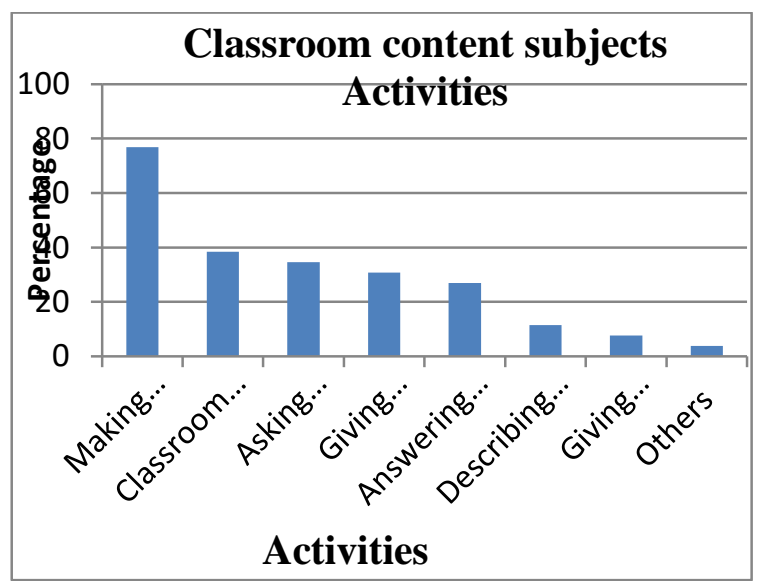

Figure 4. Content Subjects Classroom Activities

The study of students' lacks intended to know what they still need to improve in order to be communicative whilst using English, mainly in content subjects classes. In this perspective, topics that are often talked about in different subjects (about Accounting) in classroom during students'actual study in the university were investigated.

Topics Often Talked About in Content Subjects Classes

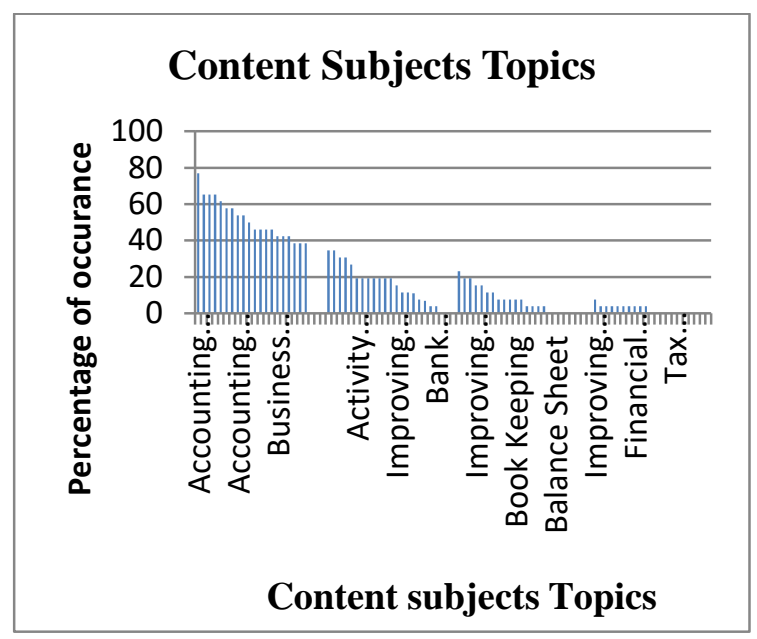

Figure 3. Classe Content Subjects Topics frequency of occurance

The results reveal that all the topics are "often" talked about. Topics like accounting basics is the most often talked about With $77 \%$ of occurrance in class content subjects. Other topics that are also talked about include accounting principles with $65 \%$, financial accounting with $65 \%$, bank accounting $62 \%$, activity based costing with $65 \%$, Tax accounting with $58 \%$, financial ratios with $58 \%$, accounting practices with $54 \%$, financial management with $50 \%$.of the total number of students.

Thus, the materials that were developed were based on the accounting topics according to students order of preferences. The accounting topics that helped to develop the materials were: accounting basics, financial accounting, and accounting concepts.

\section{Activities in Content Subjects Classes}

Data were also collected in order to find out the classroom activities that help learners to learn both the content materials and improve their English language.

Overall, the results demonstrate that students are mostly involved in making presentations. This activity is mentioned by $76.9 \%$ of the total number of participants. Meanwhile, discussion activities are mentioned by $38.5 \%$. Other activities that are actually practised in class subjects mainly include: asking questions $(34.6 \%)$, communicating in group (30.8\%). The other activities that students acknowledge to be 
involved in though these are not frequent (loooking at the percentage of occurrence) include: describing procedure (with 11.5\%), Answering lecturers' questions (with 26.9\%), giving explainations (with 7.7\%).

Students' Score of English Proficiency

Table 1. Common European Framework of Reference with TOEFL score

\begin{tabular}{|clc|}
\hline CEFR & \multicolumn{1}{c}{ levels } & $\begin{array}{c}\text { TOEFL score (total } \\
\text { cut score) }\end{array}$ \\
\hline A1 & Beginner & - \\
A2 & Intermediate (Low- & 337 \\
& Mid-High) & \\
B1 & Advanced Low & 460 \\
B2 & Advanced Mid & 543 \\
C1 & Advanced High & 627 \\
C2 & Superior & - \\
\hline
\end{tabular}

Table 2. Students' Scores of English Proficiency Test

\begin{tabular}{|c|c|c|c|c|}
\hline \multirow{3}{*}{ No. } & \multicolumn{4}{|c|}{ Types of the Test } \\
\hline & \multicolumn{2}{|c|}{ PRO-TEFL } & \multicolumn{2}{|c|}{$\begin{array}{l}\text { TOEFL like Paper- } \\
\text { based }\end{array}$} \\
\hline & Score & Level & score & Level \\
\hline 1. & 430 & Intermediate & 407 & Intermediate \\
\hline 2. & 410 & Intermediate & 478 & $\begin{array}{l}\text { Advanced } \\
\text { Low }\end{array}$ \\
\hline 3. & 435 & Intermediate & 620 & Advanced Mid \\
\hline 4. & 428 & Intermediate & 450 & Intermediate \\
\hline 5. & 467 & $\begin{array}{l}\text { Advanced } \\
\text { Low }\end{array}$ & 450 & Intermediate \\
\hline 6. & 430 & Intermediate & 330 & Intermediate \\
\hline 7. & 490 & $\begin{array}{l}\text { Advanced } \\
\text { Low }\end{array}$ & 430 & Intermediate \\
\hline 8. & 413 & Intermediate & 410 & Intermediate \\
\hline $\begin{array}{c}9 . \\
10 .\end{array}$ & & & $\begin{array}{l}453 \\
500\end{array}$ & $\begin{array}{l}\text { Intermediate } \\
\text { Advanced } \\
\text { Low }\end{array}$ \\
\hline 12. & & & 430 & Intermediate \\
\hline 13. & & & 447 & Intermediate \\
\hline 14. & & & 537 & $\begin{array}{l}\text { Advanced } \\
\text { Low }\end{array}$ \\
\hline 15. & & & 437 & Intermediate \\
\hline 16. & & & 435 & Intermediate \\
\hline 17. & & & 476 & $\begin{array}{l}\text { Advanced } \\
\text { Low }\end{array}$ \\
\hline 18. & & & 428 & Intermediate \\
\hline 19. & & & 435 & Intermediate \\
\hline 20. & & & 490 & $\begin{array}{l}\text { Advanced } \\
\text { Low }\end{array}$ \\
\hline & & Mea & & \\
\hline & 437.8 & Intermediate & 454.8 & Intermediate \\
\hline
\end{tabular}

An investigation on students' score of English Proficiency Test was also conducted. The results show that most of the students have attended an English test. Some took it once while some others took it twice. The English Tests taken are of two types: PRO-TEFL and TOEFL like Paper-based.

To decide the level of each individual students, Common European Framework of Reference for Languages served as a reference. According to this framework, scores for TOEFL/Pro-TEFL are classified according to the level of proficiency as follows.

The average of the scores of the students in both the two types of tests that were mentioned are: 437,8 for PRO-TEFL and 454.8 for those who took TOEFL like Paper-based test. Nevertheless, some students did not provide any score. By knowing the students level of English profiency, the developed materiasl are expected to fit the students' level.

\section{Students' Perception on How Well They Use} English in Class

A question was asked to obtain data on students' use of English in performing some tasks (that were thought important). To analyse the data the same tasks were grouped in four goups according to the degree of occurance from data from students'questionnaire. The goups were presented in the chart below and have been grouped according to the frequency of occurance. These groups correspond to (in the strict order of occurance): Fair, Good, Poor, and Very Good.

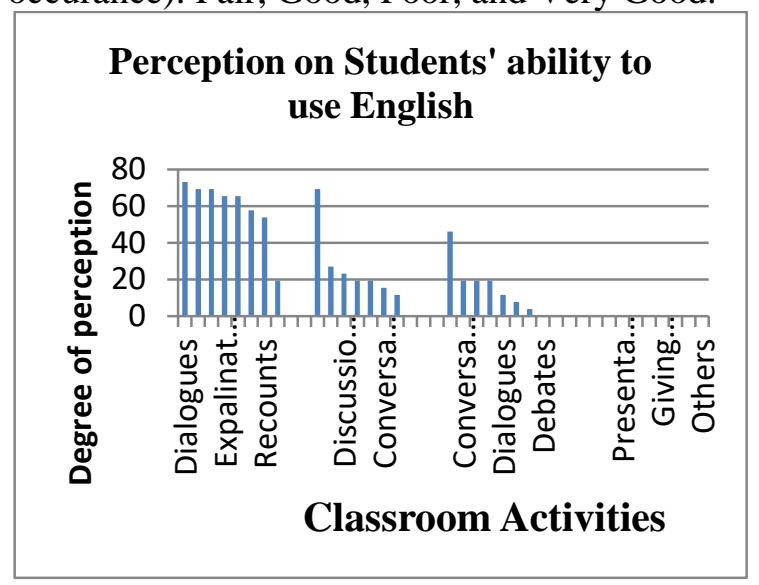

Figure 5. Activities for the use of English in Performing Classroom Tasks

The results highlight that students can "fairly" perfom all the tasks except debate (which is even not significantly fairy practised). No activity is believed to be perfomed at the level of very good. The category of some tasks is "good" but this is not significant enough. Making presentation is felt to be even more poorly performed. In the sense to know students lacks, data were collected to investigate students difficulties in 
speaking English during their content subjects class activities.

Students' Difficulties in Speaking English

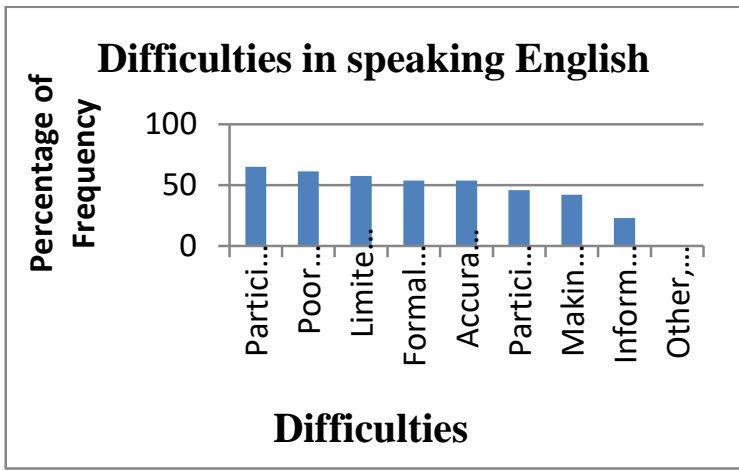

Figure 6. Students' Difficulties in Speaking English

The results from the data show that students lack of strategies to participate in discussions and/or debates. This has been mentioned by $65 \%$ of the students. They also have difficulties in pronunciation $(62 \%)$ and lack of vocabulary items especially specific vocabulary $(58 \%)$ to use. What can not be ignored is the students' lack of both formal language (54\%) and accuracy in their sentences (54\%). The two last probems are related since formal language include correctness/accuracy of sentences.

To try to overcome some of these difficulties, the University of Cambridge CLIL experienced teachers (University of Cambridge ESOL Examinations, 2008:6) propose a number of activities to help learners in such settings. These can include: tasks that involve learners in producing key-subject specific vocabulary and structures in meaningful pair or group work activities. Tasks can be at word level (e.g: pairwork information-gap, or lebelling activity) or sentence level (pairs can ask and answer questions...) or discussions in groups to explain about the content topics under discussion.

\section{WANTS}

The analysis of data on what content subjects topics students would prefer to talk about while learning speaking English reveal that the most preferred topics are (ranged in their order of importance according to students preferences) Accounting, Basics Financial Accounting, Accounting, Concepts Accounting Principles, Tax Accounting, Income Statement
Components of the English Speaking Learning Materials

Data were also collected in the sense to find out students' wants about what should the materials help them to learn.

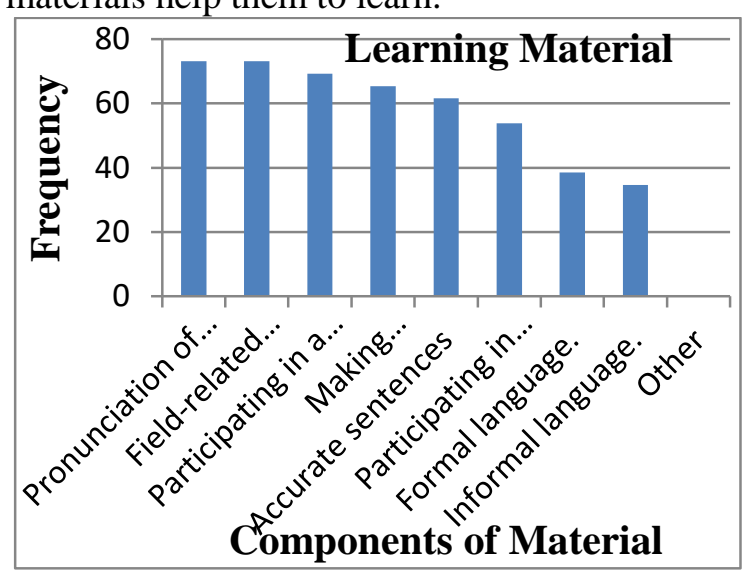

Figure 7: Students Preferences of the Components of Learning Materials

The results from the data illustrate that there are different elements of the materials according to students preferences. However, pronunciation and vocabulary specific to their area of study come at the top with $73 \%$ of occurance each. The other elements include conversations/dialogue with $69 \%$, learning about making good presentation with $65 \%$, accurate sentences with $62 \%$ and strategies about making discussions/debates with $54 \%$.

In the same sense, results from Herminingsih (2015, p. 148) about the language used in CLIL settings in a biology class include specific words and gammatical features. The results show that there is a (1) use of both high frequency general words, such as find, use, speak, continue,... (2) non-specialized academic words auch as examine, conservation, consume, preserve, ... and (3) specialised content area words (unique to specific content area) such as pollen, biosphere, chain,... The same author realises also the use of sentence patterns in grammar. These include the declaratives, the imperatives, the interrogatives, and the exclamatory sentences. These results emphasize the students' needs about learning vocabulary and grammatical features and can support the development of any CLIL related materials.

\section{English Speaking Learning Activities}

Students' wants also include activities that they would like to be doing and that will help them to really learn and practise communication. In this perspective, data were collected to know 
students' wants about the activities that they would prefer to be involved in.



Figure 8. Students' English Speaking Learning Activities

The results indicate that from all the activities, the most preferred one is "game activities" ( $81 \%$ ). This can be interpreted as students wanting to learn English in a fun way. The other type of activities which are very significant include "dialogue/conversation activities" (77\%). This is followed by "group activities"(58\%). These are the main kinds of speaking activities from the choices of the respondents. Besides, activities like "presentation activities (42\%), question and answer activities(47\%), Role-play activities (42\%), discussions activities (38\%), opinion exchange activities (35\%), problem solving activities(31\%), and spoken exchange activities $(31 \%)$ played an important role in the variation of speaking activities that were designed for students speaking practice.

On this point, Huang (2014, p. 402) in her study about chineese students' needs for learning Chinese language in the United States, he found that $90 \%$ of the students wanted to develop their speaking skills. The activities to develop skills included both pair work and role-play. Besides, the students believed that the use of movies and songs could also be useful for their speaking skills development. Kim and Yoo (2016, p. 1049) conducted a needs analysis in order to develop materials for sports students. In their results, they found that students would prefer "the classes to use various activities such as role-play and simulations so that they could practise speaking more effectively". Because the materials developed also intended to help students practise different speaking skills, activities were designed following both students'wants and what happens in actual content subject classes.
Students' Reasons for Learning English

In order to get complete insights about what the materials should make students learn, data were collected on students' reasons for learning English.

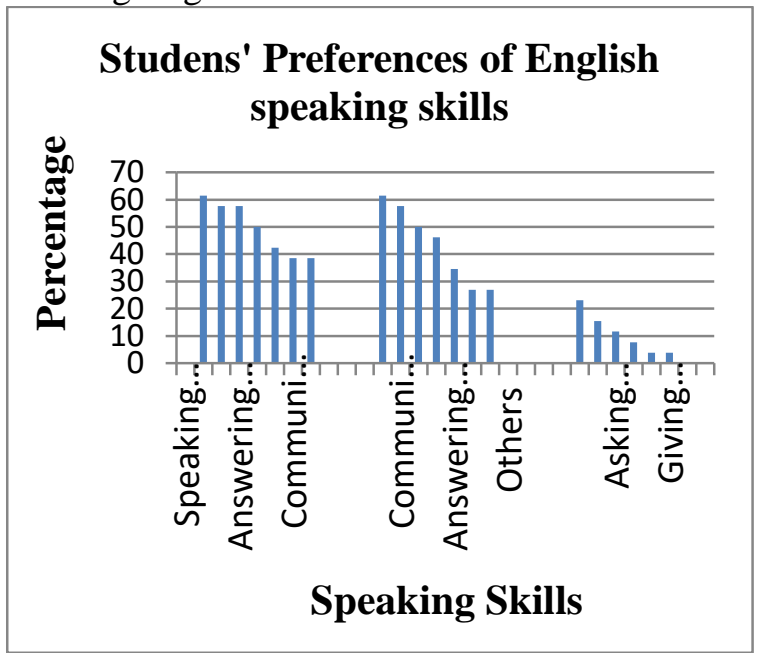

Figure 9. Students' Reasons for learning English

From the chart above, the results reveal that students are eager to learn English in order to be able to make conversations $92 \%$. Besides, being able to ask and answer questions $88 \%$, being able to make presentations $78 \%$, engage in dialogues and being able to give explaination are the main objectives of the students when they have to take the classes of Speaking English.

From the data from interview, it was found that students will need to travel abroad in the ASEAN community and communicate with people. They will also need to find jobs or create their own businesses. They also commented that they should be ready to use English and work anywhere in this global era and that they need to communicate with foreign friends. Some students also preferred materials that is based on daily conversations and dialogues that can help them to make many friends including foreigners.

Content Subjects Topics Students Would Prefer to Talk About

The analysis of data on what content subjects topics students would prefer to talk about while learning speaking English reveal that the most prefered topics are (ranged in their order of importance according to students preferences) the following: Accounting Basics, Financial Accounting, Accounting Concepts, Accounting Principles, Tax Accounting. As the materials were limited to four units, some topics were considered (according to students' order of preferences). 


\section{LingTera, 5 (1), 2018 - 85}

Dominique Savio Nsengiyumva

\section{Syllabus Design}

Based on the results from needs analysis, a syllabus was designed. Since the product was expected to be comprised of four units, this syllabus was a design of the blueprint of the four units. In each unit, this syllabus encompassed: the name of the unit, the content topic, basic competences, core competences, and the teaching/ learning materials. The teaching materials embody the language functions (the language for like describing products, expressing conditions, ...), the grammar (like the If-conditional, Relative clauses, ...), and vvocabulary (like assets, investiment, transanctions, ...). The syllabus also contained the learning aactivities. These activities were structured around CLT structure of activities, these activities included precommunicative, functional communication and social interaction activities. Each unit has time allocation as well.

For more details, the syllabus can be seen in the appendices section.

\section{Product Description}

The product of the developed materials contains elements in the table below.

Table 3: Product Components

\begin{tabular}{|c|c|c|}
\hline Unit & Title & Content Topic \\
\hline 1. & $\begin{array}{l}\text { How can I start a } \\
\text { Business? }\end{array}$ & Business \\
\hline 2. & Excuse Me Professor. & $\begin{array}{l}\text { Accounting } \\
\text { concepts }\end{array}$ \\
\hline 3. & $\begin{array}{l}\text { If I had computed all the } \\
\text { Transactions ... }\end{array}$ & $\begin{array}{l}\text { Accounting } \\
\text { basics }\end{array}$ \\
\hline 4. & In My Opinion ... & $\begin{array}{l}\text { Financial } \\
\text { accounting }\end{array}$ \\
\hline 5. & $\begin{array}{l}\text { The Income Statement } \\
\text { will be presented by ... }\end{array}$ & $\begin{array}{l}\text { Income } \\
\text { Statement }\end{array}$ \\
\hline
\end{tabular}

Each of the units is outlined as follows:

Unit title: This is based on students' needs in terms of accounting and language contents. It also expresses what can be expected to talk about in the unit.

Content of the unit: The contents include the language skills that are expected to be installed subsquent to the learning process and activities.

Warm-up activities: The warm-up activities are designed to activate students' interest and motivation on what will be delt with all along the unit activities and contents.
Main activities: These are the activities that help students to truly study and practise the language in order to achieve the intended skills.

Students self-evaluation: in this section, students evaluate to what extent they can understant the structures and perform communication using these structures. This also helps the teacher to give students feedback according to what is still missing.

Glossary: This section has in it key words that students should have graspered throughout the learning activities in the unit.

References: Each unit shows used references. These are accounting authentic contents books and some online references.

\section{Discussion}

The product in this study has been developed based on Content and Language Integrated Learning theory. The product has the quality of suplementary content and language integrated English speaking materials for accounting students. These materials will help students to increase their skills in speaking English as far as academic disciplinary contents and future carrier are concerned. The Textbook that is a result of this study has been developed following Communicative Language Teaching Steps of Activities. The materials are expected to help students to increase their level of English language proficiency from intermediate to at least mid-advanced level. The practical meaning of the product is that it can be used by teachers (tutors) to teach students in extra-curricula time.

The development of materials based on language integrated to contents for accounting students has proven that students are eager to practice materials based on subjects that reflect their everyday academic discourse as content subjects are concerned.

Prior to the development of the product materials, a number of steps have been followed. In this sense, the target needs results of accounting students'communication skills have shown that most students are eager to be able to communicate effectively in English. The idea of needs analysis is also supported by Kusmierczyk (2011, pp. 66-67) as he challenges the language materials that are more interested in "holistic communicative environment and on the communicative ideology of the workplace" instead of building students learning materials around their own needs. In this study students are interested in English that will help them in their future career. To develop future carrier related English, Li 


\section{LingTera, 5 (1), 2018 - 86}

Dominique Savio Nsengiyumva

(2014, P.182) says that 'for Business English students, their motivation of learning English might be to work in a business-related institution'. That is why there was a need to develop materials highlighting the different activities that are the picture of what students will be doing in their future carrier. Thinking that they will be involved in activities related to business, most students preferred to study materials that will help them to be communicative when they are dealing with activities related to business and using English. The content materials and activities that were developed intended to help learners study and practise the appropriate language that is used in business milieu. Thus, the evaluation of the materials show that the materials developed are appropriate for this purpose.

Though these students are eager to practice materials that reflect business activities, there was a huge need to consider their level of proficiency in English. In the analysis of students' needs it has been found that these students have the intermediate level of English proficiency.

In order to fit well the needs of the students, it was necessary to develop materials based on content and language reflecting the students' field of study contents topics. Knowing that the language used in business can vary, there was no intention to cover all the language features used in business considering students level of English proficiency and time restrictions. Students that were involved in the study appreciated the materials and enjoyed learning the contents during the try-out phase. A great number of students of accounting class showed that they want to practise speaking English especially when talking about accounting contents. This will help them to be conversant with the discourse used in accounting. Therefore, students need materials that are based on some topics of their choice. The topics in accounting are braodly various but students only main preferences were considered and were sufficiently appropriate and useful.

While students enjoyed the materials that reflect their activities in their future carrier, there was also a need to consider different main activities that students preferred to practise while studying speaking English. These (according to students' preferences) included games, discussions, conversations, and classroom presentations. They are activities that help students to be more communicative and participate both in real functional communication and social interactions. These activities were considered in this developmental study. This matches with the study of Huang, (2014, p. 402) as she studies Chinese students' needs for speaking. In the same perspectives, Karababa, and Karagül (2013, p. 367-368) study revealed that students of Turkish as foreign language preferred practising conversations (mostly with native speakers). Their subjects also valued working in groups with friends.

The conversations and group works have also been the preferences of accounting students in the present study. For their learning needs, it was also found that students want to learn about grammar: pronunciation (62\%), and specific vocabulary $(58 \%)$. The grammar, vocabulary, and pronunciation will help students to engage in structural activities proposed by communicative language teaching approach. This was not only true for this study but according to Ahmed at al. (2015, p. 9) during communication between doctors and patients there might still be misunderstanding related to issues of language such as pronunciation and vocabulary. It was in the same sense that the present study also was interested in exploring the needs of students in terms of language use.

The materials developed are based on the students' needs that have been earlier described and on content and language integrated learning. That is the reason why the present materials were built around students' field of study content topics. The product of the materials was made of four units. They included the topics about accounting such as Accounting Basics, Accounting Concepts, Financial Accounting,

Because the intended product of the materials embodied six units, the topics that the materials covered included "Business" as the topic preferred by the majority of students, Accounting Basics, also preferred by many students, Accounting Concepts, Financial Accounting, Income Statement, and Socialization. Both of the topics were choices of the students and the materials have been built around these topics. Designing materials based on topics specific to contents helps to teach students scientific and academic concepts used in the field as discussed by Remache (2013, p. 43) when he argues that 'the learning of science entails the acquisition of knowledge of certain universal concepts which are peculiar to scientific and technological texts'. In the present study, each of the units has components like title, contents, warm-up activities, main activities, students' self-reflection, a glossary, and references. Specific vocabulary and grammatical features were 
also developed in the materials of the product. The evaluation of the materials from both the students and experts show that the materials are very good considering the students' needs and level.

\section{CONCLUSION}

Exploring the needs of students in order to design materials specific to both their field of study and future carrier is not only paramount for students but for teachers as well. This makes sense as there is a great need to discover both students' necessities, lacks and wants so that the content teachers may feel at ease while using English. Exploring these needs means that the researcher has to assess them in order to discover what can be components, and activities that would be appropriate to the specific students and that should help them not only to participate in their everyday classroom activities in accounting content subjects that are taught in English but also to get conversant with the discourse that will be their own as they embrace their carrier. In order to be able to develop these appropriate materials, there is always a need to design a blueprint of an appropriate syllabus. Developing the syllabus helps to design the materials. At this level these materials may not be ready for use as they claim to meet students' needs. Therefore, the materials have to be tried out with a sample of the target students. This has the importance to reveal how well these materials can work. In this study, not only the researcher observed the materials being used by the students but he also requested students to give their feedback. This is as important as it sheds light on the appropriateness of the materials in both their necessities, wants and lacks. To truly check the materials' appropriateness, the impression of the students might not be enough. That is why it is also important to refer to experts of materials development assessment. With the try-out and experts judgement, the materials are at a phase to be considered as appropriate or not. Based on both students' and experts' assessment, the present study has shown that globally speaking the materials developed for Accounting students to practise their English were appropriate. Therefore, these materials were ready for use.

Using these materials would benefit both the students and the teachers in their classroom content subject activities. Teachers have struggles when they assign activities to students and they have many difficulties because they lack language to thoroughly engage in these activities.
Learning speaking English using the developed materials will not only help the students in being more confident in speaking English and using it in their content subjects classes but it will soften the activities of the content teachers, where English is used as well.

\section{REFERENCES}

Ahmed, F., Abel, G. A., Lloyd, C. E., Burt, J., \& Roland, M. (2015). Does the availability of a South Asian language in practices improve reports of doctor-patient communication from South Asian patients? Cross sectional analysis of a national patient survey in English general practices. BMC family practice, 16(1), 55. doi: 10.1186/s12875-015-0270-5

Cenoz, J., Genesee, F., \& Gorter, D. (2014). Critical analysis of CLIL: Taking stock and looking forward. Applied linguistics, $35(3)$, 243-262. doi:10.1093/applin/amt011

Dalton-Puffer, C. (2007). Discourse in content and language integrated learning (CLIL) Classrooms. Philadelphia: John Benjamins B.V.

de Zarobe, Y. R., \& Catalán, R. M. J. (2009). Content and language integrated learning: Evidence from research in Europe. Channel View Publications.

Devos, J. N. (2016). Peer interactions in new content and language integrated settings. Switzerland: Springer

Dudley-Evans, T., \& St John, M. J. (1998). Developments in English for specific purposes: A multi-disciplinary approach. Cambridge University Press

Herminingsih, D. I. (2015). The use of the effective vocabulary, grammar and function of English by the biology teachers. International Journal of English Language Education, 3(2), 144-157. Retrived from http://www.macrothink.org/journal/index. php/ijele/article/view/8533

Huang, C. (2014). A needs analysis for Chinese language teaching at a university in the United States. Language Learning in Higher Education, 4(2), pp. 395-422. Retrieved 24 Oct. 2018, from doi:10.1515/cercles-2014-0021

Kim, J. E., \& Yoo, H. (2016). A Sports English Teaching Model Based on Winter Sports 


\section{LingTera, 5 (1), 2018 - 88}

Dominique Savio Nsengiyumva

Instructors' Needs and Perceptions 1. International Information Institute (Tokyo). Information, 19(4), 1045-1050.

Li, J. (2014). Needs analysis: An effective way in business English curriculum design. Theory and Practice in Language Studies. 4(9), 1869-1874

Littlewood, W., \& William, L. (1981). Communicative language teaching: An introduction. Cambridge University Press.

Newton, J., \& Kusmierczyk, E. (2011). Teaching second languages for the workplace. Annual Review of Applied Linguistics, 31, 74-92.

Parsons, D. (2017). Formative assessment in discussion tasks. ELT Journal, 71(1), 2436. https://doi.org/10.1093/elt/ccw043

Remache, A. (2013). The universality of scientific discourse. International Journal of English Language Teaching, 1(2), 3752 .
Révész, A., Ekiert, M., \& Torgersen, E. N. (2014). The effects of complexity, accuracy, and fluency on communicative adequacy in oral task performance. Applied Linguistics, 37(6), 828-848.

Ruiz-Garrido, M. F., Palmer, J. C. , \& FortanetGómez, I. (2010). English for professional and academic purposes. Rodopi.

Sasson, D. (2013). Speaking and writing for English language learners: Collaborative teaching for greater success with $K$-6. Rowman \& Littlefield Education.

Tomlinson, B. (Ed.). (2011). Materials development in language teaching. Cambridge University Press.

University of Cambridge ESOL Examinations (2008). Teaching science through English: A CLIL approach. United Kingdom: Cambridge Assessment Group 